\title{
Analisis Keterlaksanaan Standar Proses Kurikulum 2013 di SMA Se-Kabupaten Kepulauan Anambas
}

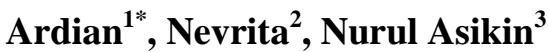 \\ ${ }^{1,2,3)}$ Program Studi Pendidikan Biologi, Fakultas Keguruan dan Ilmu Pendidikan, Universitas Maritim Raja Ali Haji, \\ Tanjungpinang, Indonesia
}

Pengiriman: 13 Juli 2019; Diterima: 2 Oktober 2019; Publikasi: Oktober 2019

\begin{abstract}
The purpose of this study is to describe the implementation of the 2013 curriculum process standards in high schools throughout the Anambas Islands District. This study uses a quantitative approach with descriptive type of research. The population of this study were all 7 biology teachers in the Anambas Islands High School in the total of 7 people, with a study sample of 4 biology teachers taken with Purposive Sampling techniques taking into account the desired data needs. Techniques and instruments for collecting data through questionnaires, observation and documentation. Questionnaire instruments are used to determine the implementation of process standards. Observation is used for knowing the level of implementation of classroom learning and documentation used to determine learning preparation. Based on the analysis of the data that has been obtained, the implementation of the standard process in learning planning obtained an average percentage of $81.83 \%$. In the implementation of learning, the percentage of the average percentage was $75.18 \%$ while the results of the learning observations in the class obtained an average percentage of $75.68 \%$. Then the assessment of learning obtained an average percentage of $72.32 \%$. The conclusion in this study is that the implementation of the 2013 curriculum process standards conducted by biology teachers has been classified as good in its implementation.
\end{abstract}

\section{Keywords: Process Standards, 2013 Curriculum, Biology Teachers}

\begin{abstract}
ABSTRAK: Tujuan penelitian ini untuk mendeskripsikan keterlaksanaan standar proses kurikulum 2013 di SMA se-Kabupaten Kepulauan Anambas. Penelitian ini merupakan penelitian yang menggunakan pendekatan kuantitatif dengan jenis penelitian deskriftif. Populasi penelitian ini adalah seluruh guru biologi di SMA Negeri se-Kabupaten Kepulauan Anambas yang berjumlah 7 orang, dengan sampel penelitian 4 orang guru biologi yang diambil dengan teknik Purposive Sampling.dengan pertimbangan kebutuhan data yang diinginkan. Teknik dan instrumen pengumpulan data melalui kuesioner, observasi dan dokumentasi. Intrumen kuesioner digunakan untuk mengetahui keterlaksanaan standar proses. Observasi digunakan untuk mengetahui tingkat pelaksanaan pembelajaran di kelas dan dokumentasi digunakan untuk mengetahui persiapan pembelajaran. Berdasarkan analisis data yang telah didapatkan, keterlaksanaan standar proses pada perencanaan pembelajaran didapatkan rata-rata persentase $81,83 \%$. Pada pelaksanaan pembelajaran didapatkan persentase rata-rata persentase $75,18 \%$ sedangkan pada hasil observasi pembelajaran di kelas didapatkan persentase rata-rata $75,68 \%$. Kemudian pada penilaian pembelajaran didapatkan persentase ratarata $72,32 \%$. Kesimpulan dalam penelitian ini bahwa keterlasanaan standar proses kurikulum 2013 yang dilakukan oleh guru biolgi sudah tergolong baik dalam pelaksanaannya.
\end{abstract}

Kata Kunci: Standar Proses, Kurikulum 2013, Guru Biologi.

*Penulis Korespondensi:

Alamat surel: ardianraza@yahoo.com 


\section{PENDAHULUAN}

Indonesia dalam meningkatkan mutu pendidikan tidak terlepas dari kebijakan pemerintah dalam menentukan arah pendidikan. Salah satu upaya pemerintah dalam meningkatkan pendidikan yaitu dengan adanya perubahan kurikulum yang sesuai dengan perkembangan zaman dan kebutuhan masyarakat. Menurut Hamalik (2013: 103) kurikulum harus disusun berdasarkan kondisi sosial-budaya masyarakat dan mengandung materi sosial-budaya dalam masyarakat. Pendidikan di Indonesia sampai saat ini mulai menerapkan kurikulum 2013. Pelaksanaan kurikulum 2013 menjadi harapan bagi semua pihak baik dari pemerintah, lembaga pendidikan dan masyarakat yang saat ini melihat pendidikan Indonesia semakin terpuruk dengan tidak adanya cerminan karakter bangsa Indonesia. Kurikulum 2013 memiliki ciri khas, antara lain kegiatan pembelajaran menggunakan pendekatan saintififik, pembentukan sikap, pengetahuan dan keterampilan secara terpadu serta penanaman pendidikan karakter. Kurikulum 2013 lebih ditekankan pada pendidikan karakter, terutama pada tingkat dasar yang akan menjadi pondasi bagi tingkat berikutnya (Mulyasa, 2015: 6).

Kegiatan proses pembelajaran merupakan bagian dari standar proses yang dicantumkan dalam standar nasional pendidikan yang dituangkan berdasarkan PP No.19 Tahun 2005 dan PP Nomor 32 Tahun 2013. Standar proses berdasarkan Permendikbud No. 22 Tahun 2016 merupakan kriteria mengenai pelaksanaan pembelajaran pada satu satuan pendidikan untuk mencapai standar kompetensi lulusan. Lembaga sekolah dalam melaksanakan standar proses kurikulum 2013 harus berjalan secara interaktif, aktif, dan menyenangkan. Terselenggaranya standar proses kurikulum 2013 diharapkan mampu dalam mengembangkan minat dan bakat peserta didik secara mandiri.

Pelaksanaan kurikulum 2013, guru memiliki peranan yang sangat penting dalam terlaksananya standar proses kurikulum 2013. Standar proses yang mencakup perencanaan, pelaksanaan dan penilaian pembelajaran yang lebih menekankan keaktifan dan kreativitas bagi seorang guru dalam menyusun dan merencanakan sebuah pembelajaran yang bermakna. Menurut Mulyasa (2015: 29) "guru harus merumuskan tujuan secara jelas, menetapkan waktu perjalanan, menetapkan jalan yang harus ditempuh, menggunakan petunjuk perjalanan, serta menilai kelancaran perjalanan sesuai kebutuhan dan kemampuan peserta didik". Standar proses kurikulum 2013 menjadi pedoman guru dalam menentukan arah pembelajaran yang menerapkan pendekatan ilmiah (Scientific Approach). Pemahaman guru mengenai standar proses menjadi poin penting dalam mengembangkan silabus, penyusunan RPP, pelaksanaan pembelajaran dengan pendekatan ilmiah, evaluasi dan refleksi oleh guru.

Dalam perencanaan pembelajaran guru harus mampu mengembangkan silabus berdasarkan SKL dan SI. Silabus dipergunakan sebagai acuan dalam mengembangkan rencana pelaksanaan pembelajaran. Guru berkewajiban dalam menyusun rencana pelaksanaan pembelajaran berdasarkan kompetensi dasar dan mengembangkannya sesuai prinsip penyusunan RPP agar dalam pelaksanaan pembelajaran di kelas terstruktur dan terarah, sehingga tujuan yang 
dikehendaki tercapai. Hubungan perencanaan pembelajaran dan pelaksanaan pembelajaran tidak dapat dipisahkan. Pelaksanaan pembelajaran di kelas yang menerapkan pendekatan ilmiah tentunya akan melibatkan peserta didik harus lebih aktif dalam memahami pembelajaran yang akan berdampak kepada peserta didik tersebut baik dampak intruksional maupun dampak penggiring. Maka dari itu guru harus mampu menentukan metode dan pendekatan pembelajaran yang digunakan sesuai dengan kemampuan peserta didik. Keberhasilan pelaksanaan pembelajaran di kelas akan diukur dengan sistem penilaian autentik. Guru sebagai pendidik harus mengetahui kriteria dan jenis penilaian yang bersifat menilai kesiapan peserta didik, proses dan hasil belajar secara terpadu sehingga akan berguna bagi guru dalam menentukan perencanaan pembelajaran yang lebih baik.

Pada dasarnya kurikulum 2013 guru merupakan aktor utama dalam mencapai tujuan pendidikan nasional. Akan tetapi di lapangan berbeda dengan apa yang kita harapkan, guru masih ada yang tidak melaksanakan tugas dan perannya sebagai pendidik. Di Kabupaten Kepulauan Anambas pembelajaran yang terjadi di dalam kelas masih belum memenuhi standar yang sesuai dengan kurikulum 2013. Kebanyakan pembelajaran masih ada yang monoton terpaku pada keaktifan guru sendiri dan keterbatasan sumber belajar yang masih kurang. Hal ini disebabkan kurangnya pemahaman guru dalam menentukan metode dan strategi pembelajaran yang tepat, kurangnya kompetensi guru dalam menentukan kesulitan peserta didik dalam belajar dan penilaian yang bersifat hanya pengerjaan soal semata.

Tingkat SMA di Kabupaten kepulauan Anambas terdiri dari SMA Negeri 1 Siantan, SMA Negeri 1 Palmatak, SMA Negeri 2 Palmatak, SMA Negeri 1 Jemaja dan SMA Negeri 1 Siantan Timur yang berstatus negeri. Kabupaten Kepulauan Anambas yang geografisnya terdiri dari gugusan pulau-pulau menjadi kesulitan dalam pemantauan dan evaluasi pelaksanaan program pendidikan. Berdasarkan hasil observasi pendahuluan di SMA Negeri 1 Siantan, kurikulum 2013 pada jenjang pendidikan SMA baru mulai diterapkan kembali di Kabupaten Kepulauan Anambas pada tahun 2017 semester ganjil pada kelas X. Dalam hal ini, membuat setiap satuan pendidikan harus bekerja keras dan dituntut untuk bisa mengimplementasikan kurikulum 2013. Tetapi dalam pelaksanaannya belum maksimal, dalam pembelajaran ternyata guru biologi masih belum sepenuhnya mengacu pada Peraturan Menteri Pendidikan dan Kebudayaan (Permendikbud) Nomor 65 Tahun 2013 tentang standar proses.

\section{METODE PENELITIAN}

Penelitian ini dilaksanakan di SMA Negeri se-Kabupaten Kepulauan Anambas yang terdiri dari 1) SMA Negeri 1 Siantan, 2) SMA Negeri 1 Palmatak, 3) SMA Negeri 1 Siantan Timur dan 4) SMA Negeri 1 Jemaja. Penelitian ini dilakukan pada semester ganjil di kelas X MIPA pada bulan November 2018. Populasi dalam penelitian ini adalah seluruh guru biologi di SMA Negeri seKabupaten Kepulauan Anambas yang berjumlah 7 orang. Sedangkan sampel pada penelitian ini sebanyak 4 orang yang diambil dengan teknik Purposive Sampling. Penelitian ini merupakan 
penelitian kuantitatif dan termasuk dalam jenis penelitian deskriftif untuk menggambarkan kondisi dilapangan.

Teknik pengumpulan data dalam penelitian ini yaitu kuesioner, observasi, dan dokumentasi. Instrumen kuesioner digunakan untuk mengetahui keterlaksanaan standar proses dalam perencanaan pembelajaran, pelaksanaan pembelajaran dan penilaian pembelajaran yang terdiri dari 33 item pernyataan. Pada instrumen observasi digunakan untuk mengetahui tingkat pelaksanaan proses pembelajaran yang dilakukan oleh guru dan peserta didik. Observasi pada penelitian ini termasuk observasi terstruktur dengan menggunakan skala Likert. Dokumentasi digunakan untuk mengetahui persiapan pembelajaran yang dilakukan oleh guru dalam pembelajaran yang berupa daftar ceklis.

\section{HASIL DAN PEMBAHASAN}

Berikut disajikan data mengenai keterlaksanaan standar proses di SMA Negeri seKabupaten Kepulauan Anambas yang meliputi perencanaan pembelajaran, pelaksanaan pembelajaran dan penilaian pembelajaran.

\section{Perencanaan Pembelajaran}

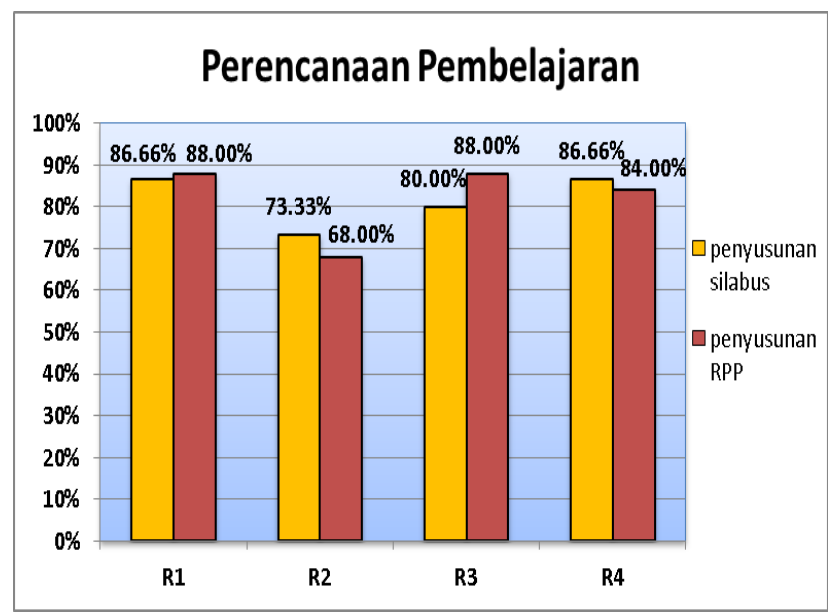

Gambar 1. Keterlaksanaan Perencanaan Pembelajaran
Berdasarkan gambar 1. bahwa secara keseluruhan guru sudah membuat perencanaan pembelajaran dengan baik dengan rata-rata persentase $81,83 \%$ yang dikategorikan hambatan rendah sekali. Berdasarkan hasil analisis yang telah disampaikan di atas, menunjukkan sebagian besar guru biologi di SMA Negeri Kabupaten Kepulauan Anambas telah mengembangkan silabus berdasarkan standar isi dan standar kompetensi lulusan. Beberapa guru juga telah menyusun dan mengembangkan RPP sesuai silabus guna mengarahkan kegiatan dalam mencapai kompetensi dasar. Pada saat ini guru hanya perlu memahami silabus dan mengembangkannya. Guru biologi di SMA Negeri se-Kabupaten Kepulauan Anambas telah memiliki pedoman dalam mengembangkan silabus dan RPP agar mempermudah guru dalam memahami dan menyusun perangkat pembelajaran.

Guru dalam mengembangkan silabus telah melakukan pemahaman pada kompetensi dasar kemudian mengaitkan materi pembelajaran dengan metode dan pendekatan saintifik yang sesuai. Dalam penyusunan RPP terlebih dahulu guru memahami silabus yang telah diberikan kemudian dikembangkan sendiri sesuai materi pembelajaran yang terkait. Guru dalam mempersiapkan pembelajaran telah berupaya mengembangkan RPP secara individu dengan memperhatikan silabus dan acuan berdasarkan kurikulum 2013.

Dalam perencanaan pembelajaran guru telah menentukan indikator-indikator dan tujuan pembelajaran yang sesuai dengan materi pembelajaran. Hal ini sesuai dengan Ariadi (2014: 52) bahwa apabila kompetensi dasar sudah dapat dicapai oleh peserta didik maka target kompetensi 
dasar tersebut sudah tercapai, sehingga dalam penyusunan RPP merumuskan indikator dan tujuan pembelajaran merupakan hal yang penting. Dalam menentukan indikator dan tujuan pembelajaran, guru harus menyesuaikan dengan KD yang telah tercantum dalam silabus dan menyelaraskan indikator dan tujuan pembelajaran sesuai dengan karakteristik dan kemampuan peserta didik. Sehingga dalam menyusun perencanaan pembelajaran guru harus berusaha memahami dan mengembangkan perangkat pembelajaran secara mandiri. Hal ini didukung dengan adanya pelatihan-pelatihan dan pembimbingan dari pihak sekolah mengenai pengembangan silabus dan RPP yang mengacu sesuai dengan kurikulum 2013.

Berdasarkan uraian hasil penelitian yang sudah diperoleh mengenai perencanaan pembelajaran, guru biologi di SMA Negeri Kabupaten Kepulauan Anambas sudah memiliki pedoman silabus dan telah melakukan pengembangan RPP sesuai dengan kurikulum 2013. Guru biologi dalam membuat perencanaan pembelajaran membutuhkan pelatihan-pelatihan yang sering dilakukan guna memahami silabus dan pengembangan RPP, sehingga pelaksanaan standar proses kurikulum 2013 dapat terlaksana dengan maksimal. Perencanaan pembelajaran yang baik tentunya akan mengarahkan kegiatan yang lebih terarah dan tercapainya tujuan pembelajaran yang diinginkan. Guru harus mampu menyusun perencanaan pembelajaran dengan sebaik-baiknya sehingga proses pembelajaran dapat terlaksana dengan baik dan memberikan hasil yang maksimal (Saroni, 2011: 50).

\section{Pelaksanaan Pembelajaran}

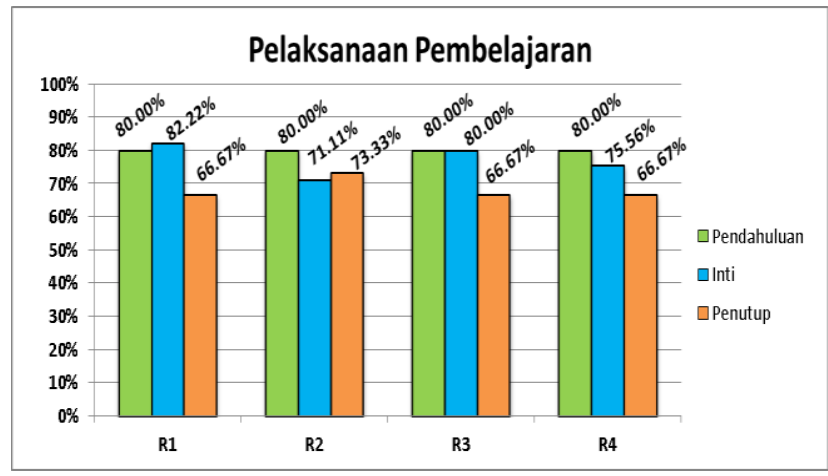

Gambar 2. Keterlaksanaan Pelaksanaan Pembelajaran

Berdasarkan gambar 2. bahwa secara keseluruhan guru sudah melakukan pelaksanaan pembelajaran dengan baik dengan persentase ratarata $75,18 \%$ yang dikategorikan hambatan rendah. Berdasarkan hasil analisis yang telah disampaikan di atas bahwa pelaksanaan kurikulum 2013 dalam pelaksanaan pembelajaran dalam kegiatan pendahuluan, inti dan penutup di SMA Negeri seKabupaten Kepulauan Anambas yang dilakukan guru biologi sudah baik. Hal ini sejalan dengan Ayuriyanti (2015: 74) bahwa pelaksanaan pembelajaran yang dilakukan guru sudah baik dengan kategori hambatan rendah. Guru sebagian besar sudah melakukan pembelajaran yang interaktif dengan menciptakan suasana belajar yang kondusif dengan memberikan humoris, tetapi karena kurikulum 2013 baru diterapkan membuat peserta didik masih asing sehingga peserta didik cenderung diam dan kurang aktif. Menurut Ariadi (2014: 54) suasana belajar yang kondusif akan membuat peserta didik nyaman sehingga berpengaruh pada hasil belajar yang baik. Dalam mengembangkan sikap, pengetahuan dan keterampilan peserta didik guru melakukan pada saat diskusi dan persentasi didepan kelas.

Demi terciptanya pembelajaran yang berpusat pada peserta didik guru menggunakan strategi/metode yang bervariasi agar peserta didik 
tidak jenuh pada saat pembelajaran. Hal ini sejalan dengan Ayuriyanti (2015: 73) bahwa dengan menggunakan salah satu metode pembelajaran akan membuat peserta didik lebih aktif dibandingkan dengan guru. Sehingga pembelajaran akan memberikan ruang yang cukup bagi peserta didik dalam mengembangkan bakat dan minat serta kreativitas dalam pembelajaran. Dalam pelaksanaan pembelajaran kurikulum 2013 guru harus mampu memberikan pemahaman yang baik kepada peserta didik. Salah satu dalam membantu pemahaman peserta didik melalui media pembelajaran dan sumber belajar yang beragam. Dengan bantuan media pembelajaran tentunya akan membuat peserta didik lebih aktif dalam pembelajaran sehingga terjadinya pembelajaran yang interaktif. Media pembelajaran yang digunakan guru belum sepenuhnya beragam karena masih terdapat keterbatasan media yang belum lengkap di sekolah sehingga guru hanya menggunakan media berupa visual yakni gambar dan lingkungan sekitar.

Dalam pelaksanaan pembelajaran kurikulum 2013 tentunya tidak terlepas dengan sumber belajar yang digunakan guru, peserta didik dan sekolah. Sumber belajar tidak hanya berpusat pada pengetahuan dari guru, peserta didik dapat mencari sumber belajar lain seperti buku, internet dan lainnya. Menurut Nurhamidah yang dikutip dari Widyasmoro (2015: 116) bahwa ketersedian buku sumber sebagai bahan ajar dan sumber belajar merupakan faktor penting dalam mendukung keberhasilan pelaksanaan kurikulum 2013. Ketersedian buku juga akan membantu peserta didik dalam memahami pembelajaran sehingga peserta didik dapat menguasai konsep ilmu pengetahuan yang dipelajari.

Keterlaksanaan pelaksanaan pembelajaran kurikulum 2013 di SMA Negeri se-Kabupaten Kepulauan Anambas ini juga didukung dengan hasil observasi guru biologi pada pelaksanaan pembelajaran di kelas.

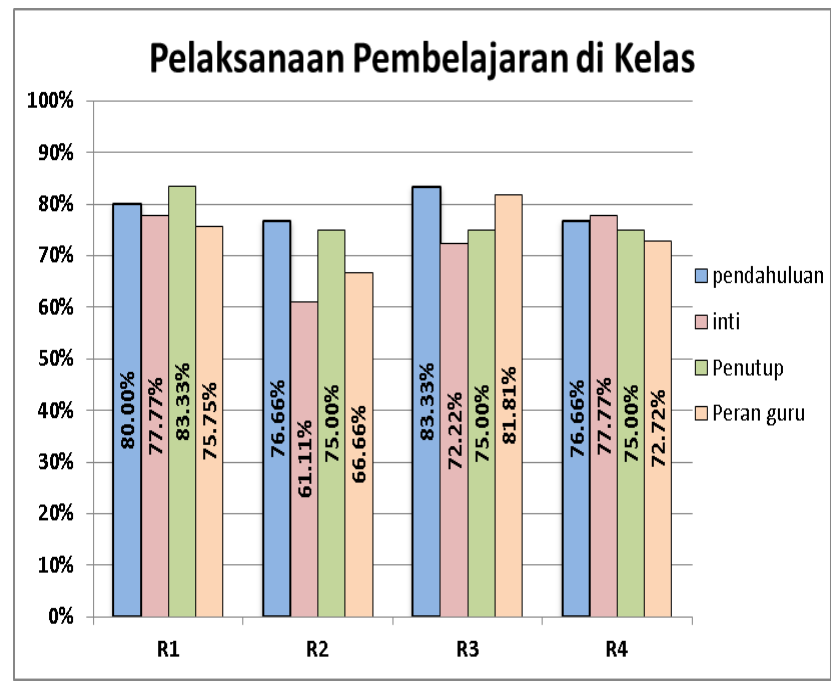

Gambar 3. Keterlaksanaan Pelaksanaan Pembelajaran di Kelas X

Berdasarkan gambar 3. bahwa secara keseluruhan guru sudah melakukan pelaksanaan pembelajaran dengan baik dengan persentase ratarata 75,68\% yang dikategorikan hambatan rendah. Berdasarkan analisis data yang telah diperoleh diatas menunjukan bahwa kegiatan pendahuluan yang dilakukan guru biologi SMA Negeri seKabupaten Kepulauan Anambas sebagian besar sudah melakukan persiapan dalam pembelajaran dengan menyiapkan peserta didik secara fisik dan psikis, melalui berbaris di depan pintu kelas, memulai doa sebelum memulai pembelajaran pada saat jam pagi dan menyanyikan lagu wajib pada saat jam siang serta memeriksa kehadiran peserta didik. Hal ini guna menanamkan karakter religius pada peserta didik agar terbiasanya dengan lingkungan masyarakat. Guru juga mengajukan 
pertanyaan-pertanyaan materi sebelumnya agar peserta didik dapat mengingat kembali pada saat keterkaitan materi sebelumnya dengan materi yang akan dipelajari pada saat itu. Peserta didik diberikan sebuah permasalahan oleh guru dengan melalui gambar, video dan lingkungan sekitar agar peserta didik dapat menganalisis permasalahan tersebut.

Proses pembelajaran kurikulum 2013 menekankan pembelajaran berpusat pada peserta didik, akan tetapi masih ada pembelajaran yang masih berpusat pada guru sehingga pembelajaran yang terjadi peserta didik kurang aktif. Hal ini terjadi disebabkan peserta didik belum bisa belajar secara mandiri dan peserta didik kurang terkontrol pada saat pembelajaran. Pada saat proses pembelajaran berlangsung guru menggunakan metode pembelajaran yang bervariasi seperti observasi, diskusi, namun masih ada guru yang menggunakan metode ceramah karena peserta didik yang cenderung diam dan kurang berpatisipasi dalam pembelajaran dikarenakan sumber belajar yang belum memadai sehingga peserta didik harus mendekati peserta didik yang lain untuk melihat ringkasan materi pembelajaran. Peserta didik yang tidak memiliki buku terkadang harus membuat catatan melalui buku teman sekelasnya sehingga membuat peserta didik lain kurang fokus dalam pembelajaran.

Media pembelajaran tentunya akan membantu guru dan peserta didik dalam pembelajaran serta akan berpangaruh pada peningkatan pengetahuan dan minat belajar peserta didik. Media yang digunakan guru dalam pembelajaran sebagian sudah bervariasi seperti powerpoint, video dan gambar. Namun guru juga ada yang masih belum menggunakan media karena keterbatasan sarana prasarana yang belum lengkap sehingga guru hanya memberikan gambar di papan tulis apa adanya saja. Menurut Hardianti (2017: 57) bahwa kurangnya fasilitas sekolah yang menunjang pelaksanaan pembelajaran maka akan menjadi hambatan guru dalam mengimplementasikan kurikulum 2013. Hal ini menyebabkan peserta didik menjadi kurang peduli dengan pembelajaran dan kurang berpikir kritis serta kurang memahami apa yang dipelajarinya.

Guru membimbing peserta didik dalam merangkum pembelajaran yang telah dilaksanakan. Pembuatan rangkuman ini bisa dalam bentuk tulisan, lisan maupun tanya jawab. Berdasarkan hasil observasi pembelajaran di kelas, guru kebanyakan memberikan rangkuman berupa lisan. Hal ini di karenakan peserta didik sudah mencatat dan merangkum materi pembelajaran pada saat proses pembelajaran berlangsung sehingga guru cukup mengulas pembelajaran secara lisan. Selain itu guru juga memberikan kesempatan kepada peserta didik agar merangkum kegiatan pembelajaran agar menumbuhkan rasa tanggung jawab dan berani didepan umum.

Sebelum pembelajaran berakhir guru juga memberikan tugas di rumah baik itu individu maupun kelompok sesuai pembelajaran yang telak dilaksanakan. Tugas merupakan salah satu penilaian yang akan dilakukan guru untuk melihat sejauh mana pemahaman peserta didik dalam belajar. Guru juga memberikan informasi mengenai pembelajaran yang akan dilakukan pada saat pertemuan selanjutnya dengan mengarahkan kepada peserta didik dalam mencari sumber belajar atau referensi materi pembelajaran. Penerapan 
kurikulum 2013 yang baru diterapkan membuat peserta didik cenderung diam dan kurang aktif dalam belajar karena sumber belajar peserta didik yang kurang memadai dan sarana prasarana yang tidak lengkap. Hal ini membuat guru harus ekstra kerja keras dan mencari cara dalam menentukan pembelajaran yang mudah dipahami peserta didik dalam belajar, sehingga waktu yang digunakan habis hanya sebatas persiapan pembelajaran dan menyebabkan pelaksanaan pembelajaran kurikulum 2013 belum sepenuhnya terlaksana.

Berdasarkan hasil penelitian yang telah diperoleh bahwa pelaksanaan pembelajaran kurikulum 2013 sebagian guru telah melaksanakannya dengan baik walaupun belum sepenuhnya terpenuhi. Guru sudah melakukan pembelajaran sesuai dengan kurikulum 2013, namun dari faktor peserta didik yang cenderung diam dan belum terbiasa dengan kurikulum 2013 sehingga dalam pelaksanaan pembelajaran peserta didik kurang aktif dan berpusat kepada guru. Kurangnya keaktifan peserta didik menjadi hambatan bagi guru dalam melaksanakan pembelajaran kurikulum 2013. Sehingga guru dituntut agar dapat mengelola kelas dengan baik agar terciptanya suasana belajar yang kondusif dengan mengontrol kegiatan pembelajaran ke arah yang lebih baik.

\section{Penilaian Pembelajaran}

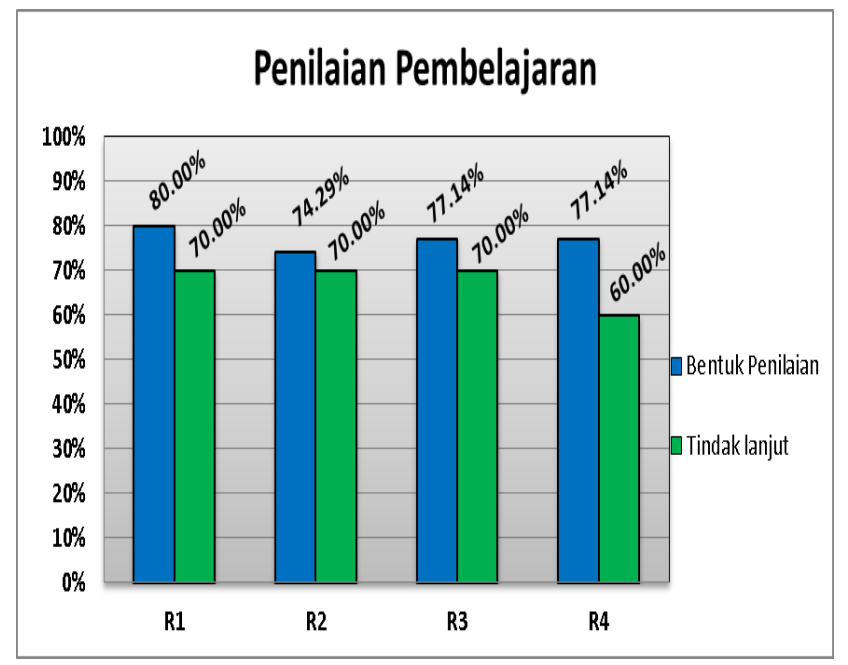

Gambar 4. Keterlaksanaan Penilaian Pembelajaran Berdasarkan gambar 4. bahwa secara keseluruhan guru sudah melakukan penilaian pembelajaran dengan baik dengan persentase ratarata $72,32 \%$ yang dikategorikan hambatan rendah. Berdasarkan hasil analisis yang telah disampaikan di atas, menunjukkan bahwa pelaksanaan standar proses kurikulum 2013 dalam penilaian pembelajaran dalam bentuk penilaian dan tindak lanjut di SMA Negeri se-Kabupaten Kepulauan Anambas yang dilakukan guru biologi sudah baik. Hal ini sejalan dengan Ayuriyanti (2015: 75) bahwa penilaian pembelajaran yang dilakukan guru sudah baik dengan kategori hambatan rendah. Guru telah menggunakan berbagai macam intrumen pembelajaran pada aspek pengetahuan, sikap dan keterampilan pada saat pembelajaran. Hal ini sejalan dengan pendapat Mujiasih yang dikutip dari Widyasmoro (2015: 175) bahwa karakteriktik penilaian kurikulum 2013 berupa penilaian autentik yang artinya memperhatikan keseimbangan antara penilaian kompetensi sikap, pengetahuan dan keterampilan. Guru juga memberikan penilaian kepada peserta didik yang terlibat aktif dalam menjawab pertanyaan dengan benar dan pada saat berdiskusi. 
Dalam penilaian pembelajaran beberapa guru belum melakukan sepenuhnya, hal ini disebabkan karena keterbatasan waktu pada saat pembelajaran sehingga penilaian peserta didik kurang terlaksana. Penilaian aspek pengetahuan guru biasa melakukan melalui tes tertulis dan lisan, agar guru dapat melihat ketercapaian kompetensi peserta didik dalam pembelajaran. Penilaian pada aspek sikap guru melihat keaktifan peserta didik dalam diskusi kelompok dan kegiatan keseharian peserta didik. Sedangkan pada aspek keterampilan guru melihat pada kecenderung penguasaan dalam memahami pembelajaran, dalam membuat produk dan kegiatan pengamatan pada saat pratikum.

Penilaian pengetahuan tidak jauh berbeda dengan KTSP tetapi penilaian kurikulum 2013 harus dinilai dari setiap aspek indikator pembelajaran sehingga guru harus mencari waktu dalam menilai tersebut. Penilaian Sikap guru melihat keaktifan peserta didik dalam belajar, apabila peserta didik itu aktif maka akan dinilai guru begitu sebaliknya. Namun dalam penilaian sikap guru susah dalam menilai karena peserta didik cenderung diam pada saat belajar. Penilaian keterampilan guru melihat dari tugas proyek, produk atau praktek peserta didik yang telah dikumpulkan. Sebagian besar guru jarang melakukan penilaian keterampilan karena keterbatasan waktu, penilaian keterampilan juga harus melihat materi yang sesuai dengan pembelajaran.

Berdasarkan hasil penelitian yang telah diperoleh bahwa dalam penilaian pembelajaran kurikulum 2013, guru telah melakukan penilaian yang sesuai dengan kurikulum 2013. Guru tidak terlalu sulit dalam menilai dari aspek pengetahuan, sikap dan keterampilan karenakan penilaian yang tidak jauh berbeda dari kurikulum sebelumnya, hanya dalam keterbatasan waktu dalam menilai sehingga guru mengalami keterlambatan dalam penilaian. Dalam penilaian pembelajaran guru tidak serta merta sekedar menilai pengetahuan, melainkan juga melakukan penialain sikap dan keterampilan. Penilaian pembelajaran tidak hanya pada saat pembelajaran di kelas tetapi juga pada luar kelas sehingga penilaian kompetensi peserta didik dapat dilaksanakan secara maksimal.

\section{KESIMPULAN DAN SARAN}

\section{Kesimpulan}

Berdasarkan hasil penelitian dapat disimpulkan bahwa keterlaksanaan Standar Proses kurikulum 2013 yang dilakukan guru biologi sudah baik. Hal ini ditunjukkan berdasarkan pada perencanaan pembelajaran yang dilakukan guru biologi didapatkan keseluruhan rata-rata persentase 81,83\%. Pada pelaksanaan pembelajaran yang dilakukan guru biologi didapatkan keseluruhan rata-rata persentase $75,18 \%$ sedangkan pada hasil observasi pelaksanaan pembelajaran yang terjadi di kelas yang dilakukan guru biologi didapatkan keseluruhan persentase rata-rata 75,68\%. Pada penilaian pembelajaran yang dilakukan guru biologi didapatkan keseluruhan rata-rata persentase $72,32 \%$.

\section{Saran}

Penelitian ini terbatas pada keterlaksanaan standar proses kurikulum 2013, penelitian selanjutnya dapat digunakan dengan keterlaksanaan standar yang lain. Diharapkan guru dapat mengembangkan kemampuan dalam 
menguasai materi pembelajaran kurikulum 2013, penggunaan metode yang sesuai dengan pendekatan saintifik kurikulum 2013, penguasaan dan pengelolaan kelas, sehingga proses pembelajaran dapat berlangsung secara interaktif, efektif dan kondusif sesuai tujuan pembelajaran yang ingin dicapai serta menghasilkan peserta didik yang berkarakter.

\section{DAFTAR PUSTAKA}

Ariadi, Didiet Chandra. 2014. Implementasi Standar Proses Kurikulum 2013 pada Pembelajaran Biologi di SMA se-Kota Magelang (Skripsi). Semarang : Universitas Negeri Semarang.

Ayuriyanti, Siswi Dwi. 2015. Hambatan Guru Dalam Perencanaan, Pelaksanaan dan Penilaian Pembelajaran Kompetensi Keahlian Multimedia Pada Penerapan Kurikulum 2013 di SMK Se Daerah Istimewa Yogyakarta (Skripsi). Yogyakarta : Universitas Negeri Yogyakata.

Hamalik, Oemar. 2013. Dasar-Dasar Pengembangan Kurikulum. Bandung : PT Remaja Rosdakarya.

Hardianti, Sitti. 2017. Implementasi Kurikulum 2013 pada Proses Pembelajaran Oleh Guru Mata Pelajaran Fisika Tingkat SMAN di Kabupaten Bone. (Skripsi). Makassar : UIN Alauddin Makassar.

Mulyasa, H. E. 2015. Guru dalam Implementasi Kurikulum 2013. Bandung : PT Remaja Rosdakarya. . 2015. Menjadi Guru Profesional : Menciptakan Pembelajaran Kreatif dan Menyenangkan. Bandung : PT Remaja Rosdakarya.

Peraturan Pemerintah RI Nomor 32 Tahun 2013 Tentang Perubahan Peraturan Pemerintah Nomor 19 Tahun 2005 Tentang Standar Nasional Pendidikan. Jakarta.

Permendikbud RI No. 22 Tahun 2016 Tentang Standar Proses Pendidikan Dasar dan Menengah. Jakarta.

Saroni, Muhammad. 2011. Personal Branding Guru : Meningkatkan Kualitas dan Profesionalitas Guru. Yogyakarta : ArRuzz Media.

Widyasmoro, Candra. 2015. Identifikasi dan Analisis Hambatan Guru Biologi Kelas
X Dalam Implementasi Standar Proses dan Standar Penilaian Kurikulum 2013 di SMA Negeri se Kabupaten Semarang (Skripsi). Semarang : Universitas Negeri Semarang. 